\title{
Effects of breed, feeding system, and lactation stage on milk fat characteristics and spontaneous lipolysis in dairy cows
}

\author{
E. Vanbergue,${ }^{*} \dagger$ L. Delaby, ${ }^{*}$ J. L. Peyraud, ${ }^{*}$ S. Colette, $\ddagger$ Y. Gallard, $\ddagger$ and C. Hurtaud ${ }^{* 1}$ \\ ${ }^{*}$ PEGASE, INRA, Agrocampus Ouest, 35590, Saint-Gilles, France \\ †Institut de l'élevage, Monvoisin, 35910 Le Rheu, France \\ łDomaine Expérimental du Pin-au-Haras, INRA, 61310, Exmes, France
}

\section{ABSTRACT}

Spontaneous lipolysis (SL) is an enzymatic reaction that leads to a release of fatty acids that can modify technological and sensory properties of milk and milk products. However, few studies have been done to assess the effect of feeding systems (FS) and breed on SL. Most of them were conducted in the 1980s and are not fully representative of cattle today. No previous study investigated the effect of cow breed at the whole-lactation scale. Thus, a trial was carried out to study the effects of 2 FS (high- and low-input FS) with 2 breeds [Holstein (HO) and Normande (NO)] during 1 entire lactation. Sixty-three cows were followed throughout 1 lactation. Cows were divided into 4 groups according to their breed and their FS. The high FS (HFS) consisted of a high-energy diet (in winter, corn silage with $30 \%$ concentrate; otherwise, pasture with $4 \mathrm{~kg} / \mathrm{d}$ of concentrate) and the low FS (LFS) consisted of a low-energy diet (in winter, conserved grass with no concentrate; otherwise, pasture with no concentrate). The cows calved between January and March. Individual milk samples were collected every month from both morning and evening milkings for fat, protein, milk fat globule size, major fatty acids and proteins profiles, and SL determinations. Data were analyzed using the mixed procedure of SAS. The SL was higher in evening milks compared with morning milks. In early lactation, in evening milks, SL was higher in LFS than in HFS. No difference was shown according to the FS in mid and late lactation. Pasture was associated with low SL rate in mid lactation. The NO cows were less susceptible to SL during the entire lactation than HO cows. Finally, early and late lactation periods were identified as being more susceptible to SL, but this depended on breed and FS. During early lactation, HO cows and LFS were

Received October 3, 2016

Accepted February 21, 2017.

${ }^{1}$ Corresponding author: Catherine.Hurtaud@inra.fr associated with higher levels of SL, particularly in evening milks, and, during late lactation, $\mathrm{HO}$ cows were associated with higher levels of SL. No intertreatment or intercow correlations (coefficient of determination $<0.16$ ) were found between SL, milk fat and protein contents, milk production, milk fat globule size, proportion of fatty acids and proteins, body condition, and weight during the entire lactation. Effects of breed, FS, and lactation stage were clearly identified and quantified. Causal mechanisms might involve energy balance and circadian secretion of milk fat globule components. Key words: free fatty acids, herd management, milk quality

\section{INTRODUCTION}

Nutritional factors and breed affect spontaneous lipolysis (SL) and thus modify technological and sensory properties of milk and milk products (Cartier and Chilliard, 1990; Deeth, 2006; Ferlay et al., 2006). Indeed, short-chain fatty acids released by the lipoprotein lipase cause development of rancid flavors, which is undesirable for consumers (Scanlan et al., 1965; Chilliard et al., 2003), and partial glycerides impair foaming and creaming abilities (Deeth, 2006). Several studies have pointed out that SL depends on lactation stage, breed, and feeding systems (FS), among other factors (Cartier and Chilliard, 1990). Conserved and fresh grass was found to induce less SL than a corn silage-based diet when energy and protein needs were met (Ferlay et al., 2006). On the contrary, low-energy diets were found to be associated with higher levels of SL, particularly in late lactation (Chazal et al., 1987; Cartier and Chilliard, 1990; Thomson et al., 2005). Several studies have shown a link between breed and SL (Chilliard, 1982; Chazal and Chilliard, 1987a; Bachman et al., 1988; Ferlay et al., 2006), and although Normande (NO) is the third ranking dairy cow breed in France and is present all over the world, no study has been done to quantify SL of NO cow milk throughout lactation. Few studies have been done to assess the effect of the interactions 
between FS and breed on SL; although interactions between breed [Holstein (HO) and NO] and diet on milk traits have been shown in various previous trials (Kolver et al., 2002; Delaby et al., 2009; Chilliard et al., 2014), none of those studies investigated the entire lactation.

Most of the studies dealing with SL in relation to dairy farming systems were conducted in the 1980s with cows having a lower potential for milk production. Genetic selection and feeding strategies have co-evolved for several decades, and genetic potential of dairy herds increased and FS changed to satisfy the energy requirements of high-genetic-merit cows. The proportion of corn silage and energy concentrate increased in dairy cow diets (Pflimlin et al., 2009); however, there is a wide range of farm practices between intensive systems maximizing $\mathrm{HO}$ cows' performances and more extensive systems prioritizing local resources and other breeds (Dillon et al., 2005; Raison et al., 2008; Le Gall et al., 2009; Peyraud and Delagarde, 2013), and the effects of these systems on SL remain unknown.

The aim of our trial was to assess the effect of 2 breeds, NO and HO, and of 2 FS, a high FS (corn silage in winter and grazing plus concentrate in spring and summer) and a low FS (conserved grass in winter and grazing with no concentrate in spring and summer), on milk SL. Effects were tracked over the entire lactation to evaluate correlations between SL, milk composition, and milk fat characteristics intertreatment, intercow, during the entire lactation, and among lactation periods (early, mid, and late lactation).

\section{MATERIALS AND METHODS}

\section{Experimental Design}

Two breeds, HO and NO, and 2 FS, a high FS (HFS) with high-energy diets and a low FS (LFS) with lowenergy diets, were used in this trial. These 2 systems corresponded to 2 different winter diets and 2 different pasture managements. Sixty-three cows were divided into 4 groups according to their FS and their breed: the HFS was composed of $15 \mathrm{HO}$ cows (8 multiparous and 7 primiparous) and $17 \mathrm{NO}$ cows (11 multiparous and 6 primiparous) and the LFS was composed of 14 $\mathrm{HO}$ cows (8 multiparous and 6 primiparous) and $17 \mathrm{NO}$ cows (14 multiparous and 4 primiparous). The other criteria for batching multiparous cows were, in order: parity, milk production, fat content, protein content, weight, BCS, and SCS. Primiparous cows were introduced in each group with the same criteria, except for the rank of lactation and milk fat and protein contents, SCC, and the number of animals in each group, to keep the same number of cows in each group. Calving was compacted from January to March 2014 and cows were monitored thorough their lactation until January 2015. Cows were milked every day at 0730 and $1730 \mathrm{~h}$. When kept indoors, cows had an average area of $10 \mathrm{~m}^{2}$ per cow.

\section{Description of FS and Diets}

HFS. From January 1 to April 3, 2014, cows received a highly digestible diet ad libitum composed of corn silage ( $55 \%$ of DM of the diet), dried alfalfa ( $16 \%$ of DM of the diet), rapeseed meal (4\% of DM of the diet), and energy concentrate (25\% of DM of the diet). Concentrate was composed, on a DM basis, of $45 \%$ soybean meal, $12 \%$ wheat, $12 \%$ corn, $12 \%$ barley $11 \%$ beets pulp, $4 \%$ molasses, and $4 \%$ minerals. From April 3 to 15 , cows were in dietary transition to turn out to pasture. From April 15 to November 17, cows were grazing white clover (15-20\%) and perennial ryegrass (80-85\%) pastures, received $4 \mathrm{~kg} / \mathrm{d}$ of concentrates, and were given between 3 and $8 \mathrm{~kg}$ of $\mathrm{DM} / \mathrm{d}$ of corn silage when grass growth was not sufficient to cover the cows' needs. The mean surface allocated per cow was 0.22 ha of pasture from April 15 to July 10, and 0.33 ha of pasture from July 10 to November 17. Cows were managed on a simplified rotational grazing system (Hoden et al., 1991; Delaby and Peyraud, 2003) based on 3 to 4 plots in spring and extended to 5 plots in autumn. From November 17 to December 31, 2014, cows received $5 \mathrm{~kg}$ of DM/d of corn silage, $4 \mathrm{~kg} / \mathrm{d}$ of concentrate, and grass silage ad libitum. Diets were formulated to meet cows' requirements (Institut National de la Recherche Agronomique, 2007). Nutritive values of forages, concentrates, and winter diets are presented in Tables 1 and 2 .

LFS. From January 1 to April 3, 2014, cows received grass silage $(50 \%$ of DM of the diet), haylage ( $48 \%$ of $\mathrm{DM}$ of the diet), and minerals (2\% of DM of the diet) ad libitum. From April 3 to April 15, cows were in dietary transition to turn out to pasture. From April 15 to November 17, cows were grazing white clover (15-20\%) and perennial raygrass (80-85\%) pastures. The total area allocated per cow was 0.22 ha of pasture from April 15 to July 10, and 0.55 ha of pasture from July 10 to November 17. Cows received grass silage when grass growth was not sufficient. Grazing management was the same as in the HFS treatment. From November 17 to December 31, 2014, cows received grass silage ad libitum. Cows did not receive any concentrate during their entire lactation. Diets were formulated to meet $80 \%$ of the energy of cows' diet in HFS (Institut National de la Recherche Agronomique, 2007). Nutritive values of forages, concentrates, and winter diets are presented in Tables 1 and 2 . 
Table 1. Chemical composition and nutritional value of winter feeds

\begin{tabular}{|c|c|c|c|c|c|c|}
\hline Item & Corn silage & Grass silage & Haylage & Concentrate $^{1}$ & Rapeseed meal & Dried alfalfa \\
\hline $\mathrm{OM}(\mathrm{g} / \mathrm{kg}$ of $\mathrm{DM})$ & 965 & 922 & 910 & 896 & 922 & 884 \\
\hline $\mathrm{CP}(\mathrm{g} / \mathrm{kg}$ of $\mathrm{DM})$ & 61 & 90 & 120 & 278 & 378 & 164 \\
\hline $\mathrm{NDF}(\mathrm{g} / \mathrm{kg}$ of $\mathrm{DM})$ & 445 & 519 & 541 & 140 & 368 & 368 \\
\hline $\operatorname{ADF}(\mathrm{g} / \mathrm{kg}$ of $\mathrm{DM})$ & 249 & 313 & 303 & 73 & 232 & 232 \\
\hline Fat $(\mathrm{g} / \mathrm{kg}$ of $\mathrm{DM})$ & 33 & 23 & 21 & 23 & 20 & 20 \\
\hline
\end{tabular}

${ }^{1}$ Concentrate: $45 \%$ soy meal, $12 \%$ wheat, $12 \%$ corn, $12 \%$ barley, $11 \%$ beet pulp, $4 \%$ minerals, $4 \%$ molasses.

${ }^{2} \mathrm{CF}=$ crude fiber.

${ }^{3} \mathrm{PDIE}=$ protein digested in the small intestine potentially synthesized in regard to energy available in the rumen (Institut National de la Recherche Agronomique, 2007).

${ }^{4} \mathrm{PDIN}=$ protein digested in the small intestine potentially synthesized in regard to nitrogen available in the rumen (Institut National de la Recherche Agronomique, 2007).

\section{Measures, Sample Collection, and Laboratory Analysis}

Measures. Milk yield was recorded at every milking. Animals were weighed every week during the entire lactation. We only showed data corresponding to milk sampling. Body condition score was recorded every month using the French notation scale of 0 to 5 (Bazin et al., 1984).
Sample Collection. During the entire lactation, animals were milked in a milking parlor twice a day at 0730 and $1730 \mathrm{~h}$. The milking procedure was adapted to collect milk samples. Milk samples were obtained by milking the cows into milk cans at morning and evening milkings, once or twice a month during the entire lactation. We collected 4 vials of $70 \mathrm{~mL}$ for the analyses described below. Milk samples were obtained on January 28, February 25, March 25, April 15, May

Table 2. Ingredients and chemical and nutritional composition of winter diets

\begin{tabular}{|c|c|c|}
\hline Item & $\mathrm{HFS}^{1}$ & LFS $^{2}$ \\
\hline \multicolumn{3}{|l|}{ Ingredient (\% DM) } \\
\hline Corn silage & 55 & - \\
\hline Grass silage & - & 50 \\
\hline Haylage & - & 48 \\
\hline Concentrate $^{3}$ & 25 & - \\
\hline Rapeseed meal & 4 & - \\
\hline Dried alfalfa & 16 & - \\
\hline Minerals & - & 2 \\
\hline \multicolumn{3}{|c|}{ Chemical composition (g/kg of DM, unless noted) } \\
\hline $\mathrm{DM}(\%)$ & 57.3 & 56.6 \\
\hline $\mathrm{OM}$ & 933 & 898 \\
\hline $\mathrm{CP}$ & 144 & 103 \\
\hline $\mathrm{CF}^{4}$ & 160 & 269 \\
\hline NDF & 353 & 519 \\
\hline $\mathrm{ADF}$ & 202 & 302 \\
\hline Fat & 27.9 & 21.6 \\
\hline \multicolumn{3}{|c|}{ Nutritional value (g/kg of DM, unless noted) } \\
\hline $\mathrm{NE}_{\mathrm{L}}(\mathrm{kJ} / \mathrm{kg}$ of $\mathrm{DM})$ & 6.84 & 6.75 \\
\hline $\mathrm{PDIE}^{5}$ & 90 & 79 \\
\hline PDIN $^{6}$ & 94 & 64 \\
\hline DMI & 18.5 & 15.1 \\
\hline \multicolumn{3}{|c|}{${ }^{1} \mathrm{HFS}=$ high feeding system. } \\
\hline \multicolumn{3}{|c|}{${ }^{2} \mathrm{LFS}=$ low feeding system. } \\
\hline \multirow{2}{*}{\multicolumn{3}{|c|}{$\begin{array}{l}{ }^{3} \text { Concentrate: } 45 \% \text { soy meal, } 12 \% \text { wheat, } 12 \% \text { corn, } 12 \% \text { barley, } 11 \% \text { beet pulp, } 4 \% \text { minerals, } 4 \% \text { molasses. } \\
{ }^{4} \mathrm{CF}=\text { crude fiber. }\end{array}$}} \\
\hline & & \\
\hline \multicolumn{3}{|c|}{$\begin{array}{l}{ }^{5} \mathrm{PDIE}=\text { protein digested in the small intestine potentially synthesized in regards to energy available in the } \\
\text { rumen (Institut National de la Recherche Agronomique, 2007). }\end{array}$} \\
\hline \multicolumn{3}{|c|}{$\begin{array}{l}{ }^{6} \mathrm{PDIN}=\text { protein digested in the small intestine potentially synthesized in regards to nitrogen available in the } \\
\text { rumen (Institut National de la Recherche Agronomique, 2007). }\end{array}$} \\
\hline
\end{tabular}


13, June 3, July 8, July 22, August 19, September 16, October 21, November 18, and December 16.

Laboratory Analyses. Milk was kept at $4^{\circ} \mathrm{C}$ after sampling. Analyses were performed at the Normandy Interprofessional Milk Analysis Laboratory (LILANO, Saint-Lô, France). Milk fat, protein, and lactose contents, SFA, C16:0, C18:0, UFA, cis-9 C18:1, PUFA, $\beta-\mathrm{CN}, \alpha_{\mathrm{S}^{-}} \mathrm{CN}, \alpha_{\mathrm{S}_{2}} \mathrm{CN}, \kappa-\mathrm{CN}, \beta-\mathrm{LG}$, and $\alpha-\mathrm{LA}$ percentages were determined by mid-infrared spectrometry (MilkoScan FT6000, Foss, Hillerød, Denmark; Ferrand-Calmels et al., 2014; Gelé et al., 2014) and SCS by flow cytometry. Two samples were collected per cow to calculate SL by the difference between free fatty acid content after $24 \mathrm{~h}$ of storage at $4^{\circ} \mathrm{C}$ and initial free fatty acid content. Immediately after milking, a 50-mL sample was heated in a water bath at $100^{\circ} \mathrm{C}$ for $2.5 \mathrm{~min}$ to stop lipase activity, and then kept at $4^{\circ} \mathrm{C}$. A second sample was stored at $4^{\circ} \mathrm{C}$ for $24 \mathrm{~h}$, then heated and kept at $4^{\circ} \mathrm{C}$ in the same way. Free fatty acid analyses were performed on both samples by the copper soap method (Vanbergue et al., 2016; Shipe et al., 1980). A sample was collected and kept at room temperature with potassium dichromate (Merck, Darmstadt, Germany) to evaluate milk fat globule (MFG) size distribution by laser light scattering (Mastersizer 3000, Malvern Instruments, Malvern, UK). Samples were measured by diluting 1:6 vol with EDTA/NaOH buffer $(0.5 M, \mathrm{pH}=$ $8)$ to dissociate casein micelles. The average diameters

$\left[\mathrm{d}_{3,2}=\sum\left(\mathrm{N}_{\mathrm{i}} \times \mathrm{d}_{\mathrm{i}}^{3}\right) / \sum\left(\mathrm{N}_{\mathrm{i}} \times \mathrm{d}_{\mathrm{i}}^{2}\right) ; \mathrm{d}_{4,3}=\sum\left(\mathrm{N}_{\mathrm{i}} \times \mathrm{d}_{\mathrm{i}}^{4}\right) / \sum\left(\mathrm{N}_{\mathrm{i}} \times \mathrm{d}_{\mathrm{i}}^{3}\right)\right]$

and median diameter $\left(\mathrm{d}_{50}\right)$ were calculated by the Malvern Instruments software. In the equation, $\mathrm{N}_{\mathrm{i}}$ is the number of fat globules in a size class of diameter $d_{i}$.

\section{Calculation and Statistical Analyses}

To facilitate further interpretations, the lactation period (LPeriod) of the trial was divided into 4 periods according to the main variation factors, which are mixed in the trial: nature of forage, lactation stage, and season (Figure 1). The first period went from January to March, where cows were in early lactation (average lactation stage: $43 \pm 21 \mathrm{~d}$; nonpregnant cows), and fed with the winter diet (corn silage vs. conserved grass). The second period went from April to June, the spring period, where cows were in early or mid-lactation (average lactation stage: $99 \pm 34 \mathrm{~d}$; average gestation stage: $3 \pm 30 \mathrm{~d}$ ) and grazing. The third period went from July to September, the summer period, where cows were in mid lactation (average lactation stage: $189 \pm 39 \mathrm{~d}$; average gestation stage: $94 \pm 36 \mathrm{~d}$ ) and grazing. The fourth period went from October to December, the autumn period, where cows were in late lactation (average lactation stage: $304 \pm 42 \mathrm{~d}$; average gestation stage: $194 \pm 33 \mathrm{~d}$ ) and receiving pasture, conserved grass, and corn silage according to forage supplies.

All statistical analyses on the data set were performed using SAS software (ver. 9.2, SAS Institute Inc., Cary, NC). The statistical significance threshold was set to $P$ $<0.05$. Trend was set to $P<0.10$. Normality of data was checked using the Shapiro-Wilk test of the SAS package univariate procedure. The effects of breed, FS, parity, and their interactions on milk traits were assessed by period using the mixed procedure of SAS for repeated measures on every sampling period (SPeriod in the model) according to the statistical model:

$$
\begin{gathered}
\mathrm{Y}_{i j k l m}=\mu+\operatorname{parity}_{i}+\operatorname{breed}_{j}+\mathrm{FS}_{k}+\text { SPeriod }_{l} \\
+\operatorname{parity}_{i} \times \text { breed }_{j}+\operatorname{parity}_{i} \times \mathrm{FS}_{k}+\operatorname{parity}_{i} \\
\times \operatorname{SPeriod}_{l}+\operatorname{breed}_{j} \times \mathrm{FS}_{k}+\operatorname{breed}_{j} \times \operatorname{SPeriod}_{l} \\
+\mathrm{FS}_{k} \times \operatorname{SPeriod}_{l}+\varepsilon_{i j k l m},
\end{gathered}
$$

where $\mu$ is the mean and $Y_{i j k l m}$ is the variable dependent

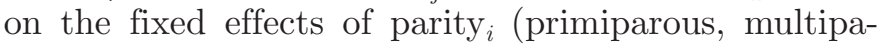
rous), $\operatorname{breed}_{j}(\mathrm{HO}, \mathrm{NO}), \mathrm{FS}_{k}$ (HFS, LFS) during Speri$\operatorname{od}_{l}$ (15 periods of sampling during the entire lactation) and their interactions, $\varepsilon_{i j k l m}$ is the residual error associated with each $i j k l m$ observation for every $i j k l$ value, and $m$ corresponds to the $m$ th observation for every $i j k l$ value. Individual effects were treated as random effects.

The effects of breed, FS, parity, and their interactions on milk fat characteristics (SL, MFG size, fatty acid profile) were assessed by period using the mixed procedure of SAS for repeated measures on every sampling period (SPeriod in the model) according to the statistical model:

$$
\begin{gathered}
\mathrm{Y}_{\text {hijklm }}=\mu+\operatorname{milking}_{h}+\operatorname{parity}_{i}+\operatorname{breed}_{j}+\mathrm{FS}_{k} \\
+ \text { SPeriod }_{l}+\operatorname{parity}_{i} \times \text { breed }_{j}+\operatorname{parity}_{i} \times \mathrm{FS}_{k} \\
+\operatorname{parity}_{i} \times \text { SPeriod }_{l}+\operatorname{breed}_{j} \times \mathrm{FS}_{k}+\text { breed }_{j} \\
\times \operatorname{SPeriod}_{l}+\mathrm{FS}_{k} \times \operatorname{SPeriod}_{l}+\varepsilon_{h i j k l m},
\end{gathered}
$$

where $\mu$ is the mean and $Y_{h i j k l m}$ is the variable depen-

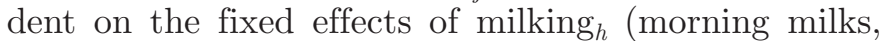
evening milks) parity $_{i}$ (primiparous, multiparous), $\operatorname{breed}_{j}(\mathrm{HO}, \mathrm{NO}), \mathrm{FS}_{k}$ (HFS, LFS) during Speriod $_{l}(15$ periods of sampling during the entire lactation) and their interactions, $\varepsilon_{h i j k l m}$ is the residual error associated with each hijklm observation, and $m$ corresponds to the $m$ th observation for every $i j k l$ value. Individual effects were treated as random effects.

The effect of the lactation period (Lperiod) on milk traits and milk fat characteristics was assessed by using the mixed procedure of SAS for repeated measures on 


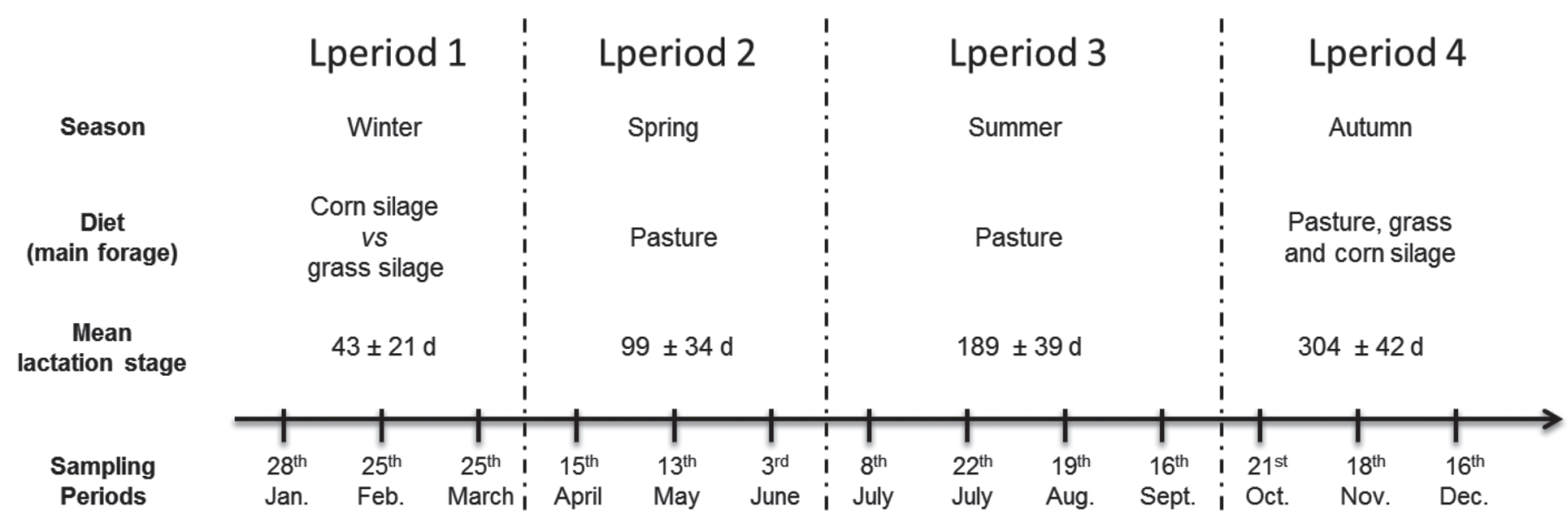

Figure 1. Diagram of the experimental design. Lperiod = lactation period.

every SPeriod within LPeriod according to the statistical model:

$$
\begin{gathered}
\mathrm{Y}_{i j k l m}=\mu+\operatorname{parity}_{i}+\text { breed }_{j}+\mathrm{FS}_{k}+\text { LPeriod }_{m} \\
+\operatorname{parity}_{i} \times \text { breed }_{j}+\operatorname{parity}_{i} \times \mathrm{FS}_{k}+\operatorname{parity}_{i} \\
\times \operatorname{LPeriod}_{m}+\operatorname{breed}_{j} \times \mathrm{FS}_{k}+\operatorname{breed}_{j} \times \text { LPeriod }_{m} \\
+\mathrm{FS}_{k} \times \operatorname{LPeriod}_{m}+\varepsilon_{i j k l m},
\end{gathered}
$$

where $\mu$ is the mean and $\mathrm{Y}_{i j k l m}$ is the variable dependent

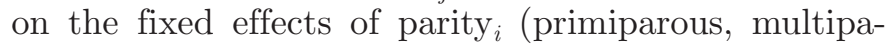
rous), $\operatorname{breed}_{j}(\mathrm{HO}, \mathrm{NO}), \mathrm{FS}_{k}$ (HFS, LFS), $\operatorname{LPeriod}_{m}$ (4 periods as explained below), and their interactions, and $\varepsilon_{i j k l m}$ is the residual error associated with each $i j k l m$ observation. Individual effects were treated as random effects.

Correlations between SL and milk yield, fat content, fat yield, protein content, protein yield, SCC, lactose content, MFG size, SFA, C16:0, C18:0, UFA, cis-9 C18:1, PUFA, $\beta-\mathrm{CN}, \alpha_{\mathrm{S}^{-}} \mathrm{CN}, \alpha_{\mathrm{S}_{2}} \mathrm{CN}, \kappa-\mathrm{CN}, \beta-\mathrm{LG}$, $\alpha-\mathrm{LA}$, weight, and BCS intertreatment, intercow, during lactation, and within Lperiods, were assessed by using the CORR procedure of SAS.

\section{RESULTS}

\section{Effect of Breed and FS on Zootechnical Parameters and Milk Fat Characteristics}

No significant interaction between breed and FS effects were identified on milk traits. Milk yield was significantly higher for $\mathrm{HO}$ cows compared with $\mathrm{NO}$ cows during the entire lactation $(9.6,6.7,4.5$, and $2.8 \mathrm{~kg} / \mathrm{d}$, respectively, for the 4 periods) and was significantly higher in HFS during periods 1,2 , and $3(9.9,5.4$, and $6.9 \mathrm{~kg} / \mathrm{d}$, respectively; Table 3 ).
Milk Composition. Fat content was lower for HO cows compared with $\mathrm{NO}$ cows during periods 2,3 , and $4(-0.46,-0.70$, and -0.86 percentage unit, respectively). Fat yield was higher for $\mathrm{HO}$ cows compared with NO cows during periods 1 and 2 and tended to be higher in period $3(281,152$, and $65 \mathrm{~g} / \mathrm{d}$, respectively) and lower during period $4(-195 \mathrm{~g} / \mathrm{d})$. Fat content was lower in HFS compared with LFS during period 1 $(-0.45$ percentage unit) and tended to be higher during period 4 (0.34 percentage unit). Fat yield was higher in HFS during periods 1, 2, and 3 (480, 152, and $124 \mathrm{~g} / \mathrm{d}$, respectively).

Milk protein content was lower and protein yield was higher for $\mathrm{HO}$ cows compared with $\mathrm{NO}$ during the entire lactation $(-0.36,-0.48,-0.39$, and -0.39 percentage unit for protein content and 193, 97, 80, and $64 \mathrm{~g} / \mathrm{d}$ for protein yield, respectively, for the 4 periods). Protein content tended to be higher in HFS than in LFS during period 2 and was higher during period $4[0.13(P=$ 0.057 ) and 0.28 percentage unit, respectively]. Protein yield was higher in HFS than in LFS during periods 1,2 , and 3 (341, 189, and $129 \mathrm{~g} / \mathrm{d}$, respectively) and tended to be higher during period $4(60 \mathrm{~g} / \mathrm{d})$. Lactose content tended to be higher in LFS in period $1(0.26$ percentage unit) and was higher in period 4, only for HO cows (0.26 percentage unit). No significant effect of breed and FS was revealed on SCS except a higher SCS in HFS during period 3.

Weight and BCS. Weight of animals did not differ between breeds and was higher in HFS compared with LFS (71 kg) during the entire lactation (Table 4). Body condition score was lower for HO cows compared with NO cows ( -0.70 points) and was higher in HFS than in LFS (0.4 points) during the entire lactation (Table 4).

MFG Size. Effects of breed and FS on MFG size were different according to periods and milking times throughout lactation. Milk fat globules were signifi- 
cantly larger for $\mathrm{NO}$ cows than for $\mathrm{HO}$ cows in evening milks during period $1\left(\mathrm{~d}_{4.3}=0.27 \mu \mathrm{m}\right.$; Table 5$)$, in morning milks during period $2\left(\mathrm{~d}_{4.3}=0.31 \mu \mathrm{m}\right)$, and in morning and evening milks during periods 3 and 4 (period $3, \mathrm{~d}_{4,3}=0.41$ and $0.39 \mu \mathrm{m}$; period $4, \mathrm{~d}_{4,3}=0.40$ and $0.27 \mu \mathrm{m}$, respectively, for morning and evening milks; Tables 5, 6, and 7).

Milk fat globules were smaller for HFS compared with LFS in morning milks during periods 1 and 3 $(-0.30$ and $-0.24 \mu \mathrm{m}$, respectively; Tables 5 and 7$)$. No significant effect of FS was detected during period 2 (Table 6). During period 4, MFG was larger for HFS in morning and evening milkings $(0.23$ and $0.33 \mu \mathrm{m}$, respectively; Table 8 ).

Fatty Acid Proportions. Saturated fatty acid percentage was higher for $\mathrm{NO}$ cows compared with $\mathrm{HO}$ cows in morning and evening milks during periods 1,2 , and $3($ period $1=6.0$ and 7.3 percentage unit; period 2 $=2.6$ and 2.1 percentage unit; period $3=1.7$ and 1.9 percentage unit, respectively, in morning and evening milks; Tables 5, 6 and 7). The MUFA percentage was lower for NO cows compared with $\mathrm{HO}$ cows during periods 1 and 2 and tended to be lower during period 3 in morning and evening milks (period $1=5.8$ and 7.1 percentage unit; period $2=2.3$ and 2.0 percentage unit; and period $3=-1.5$ and -1.4 percentage unit, respectively, for morning and evening milks; Tables 5, 6 and 7). The cis-9 C18:1 percentage was lower for NO cows in morning and evening milkings during periods 1 and 2 (period $1=-6.2$ and -4.6 percentage unit, and period $2=-1.6$ and -1.6 percentage unit, respectively, for morning and evening milks; Tables 5 and 6 ).

Feeding system had no significant effect on SFA content except during period 1, where SFA percent-

Table 3. Effect of breed and feeding strategy on milk traits during each period of lactation

\begin{tabular}{|c|c|c|c|c|c|c|c|c|}
\hline \multirow[b]{2}{*}{ Item } & \multicolumn{2}{|c|}{$\mathrm{HO}^{1}$} & \multicolumn{2}{|c|}{$\mathrm{NO}^{2}$} & \multirow[b]{2}{*}{$\mathrm{RMSE}^{3}$} & \multicolumn{3}{|c|}{$P$-value } \\
\hline & $\mathrm{HFS}^{4}$ & $\mathrm{LFS}^{5}$ & HFS & LFS & & Breed & $\begin{array}{l}\text { Feeding } \\
\text { system }\end{array}$ & $\begin{array}{c}\text { Breed } \times \\
\text { feeding system }\end{array}$ \\
\hline \multicolumn{9}{|l|}{ Period 1} \\
\hline Milk yield (kg/d) & 37.4 & 25.1 & 25.4 & 18.0 & 5.70 & $<0.001$ & $<0.001$ & 0.093 \\
\hline Fat content $(\%)$ & 3.22 & 3.86 & 3.58 & 3.85 & 0.681 & 0.243 & 0.004 & 0.185 \\
\hline Protein content (\%) & 2.91 & 2.75 & 3.28 & 3.10 & 0.519 & 0.003 & 0.156 & 0.922 \\
\hline Fat yield $(\mathrm{g} / \mathrm{d})$ & 1,202 & 953 & 912 & 681 & 281.9 & $<0.001$ & 0.001 & 0.892 \\
\hline Protein yield (g/d) & 1,084 & 678 & 827 & 550 & 202.7 & $<0.001$ & $<0.001$ & 0.165 \\
\hline SCS & 4.60 & 4.70 & 4.82 & 4.90 & 0.784 & 0.211 & 0.618 & 0.857 \\
\hline Lactose (\%) & 4.83 & 4.99 & 4.52 & 4.88 & 0.646 & 0.122 & 0.059 & 0.411 \\
\hline \multicolumn{9}{|l|}{ Period 2} \\
\hline Milk yield (kg/d) & 29.6 & 23.6 & 22.3 & 17.5 & 4.80 & $<0.001$ & $<0.001$ & 0.331 \\
\hline Fat content $(\%)$ & 3.50 & 3.75 & 4.00 & 4.22 & 0.628 & $<0.001$ & 0.114 & 0.963 \\
\hline Protein content (\%) & 2.90 & 2.79 & 3.40 & 3.25 & 0.321 & $<0.001$ & 0.057 & 0.749 \\
\hline Fat yield $(\mathrm{g} / \mathrm{d})$ & 1,041 & 877 & 877 & 737 & 217.1 & 0.004 & 0.004 & 0.805 \\
\hline Protein yield (g/d) & 858 & 656 & 748 & 572 & 149.0 & 0.005 & $<0.001$ & 0.686 \\
\hline SCS & 4.90 & 4.83 & 5.20 & 4.89 & 0.524 & 0.144 & 0.121 & 0.280 \\
\hline Lactose (\%) & 4.79 & 4.79 & 4.79 & 4.86 & 0.540 & 0.711 & 0.705 & 0.689 \\
\hline \multicolumn{9}{|l|}{ Period 3} \\
\hline Milk yield (kg/d) & 21.1 & 17.7 & 16.7 & 13.2 & 4.15 & $<0.001$ & 0.002 & 0.954 \\
\hline Fat content $(\%)$ & 3.61 & 3.69 & 4.20 & 4.50 & 0.607 & $<0.001$ & 0.135 & 0.357 \\
\hline Protein content (\%) & 3.22 & 3.22 & 3.67 & 3.55 & 0.291 & $<0.001$ & 0.380 & 0.322 \\
\hline Fat yield $(\mathrm{g} / \mathrm{d})$ & 766 & 646 & 705 & 577 & 161.0 & 0.098 & 0.002 & 0.904 \\
\hline Protein yield (g/d) & 673 & 565 & 614 & 464 & 121.0 & 0.008 & $<0.001$ & 0.449 \\
\hline SCS & 5.06 & 4.92 & 5.36 & 4.98 & 0.447 & 0.102 & 0.018 & 0.226 \\
\hline Lactose (\%) & 4.74 & 4.72 & 4.70 & 4.66 & 0.294 & 0.406 & 0.604 & 0.887 \\
\hline \multicolumn{9}{|l|}{ Period 4} \\
\hline Milk yield (kg/d) & 10.4 & 10.4 & 8.8 & 6.5 & 3.50 & 0.005 & 0.218 & 0.176 \\
\hline Fat content $(\%)$ & 4.63 & 4.19 & 5.39 & 5.14 & 0.774 & $<0.001$ & 0.097 & 0.585 \\
\hline Protein content (\%) & 3.87 & 3.57 & 4.24 & 3.99 & 0.477 & 0.004 & 0.039 & 0.854 \\
\hline Fat yield $(\mathrm{g} / \mathrm{d})$ & 537 & 500 & 372 & 276 & 158.9 & $<0.001$ & 0.146 & 0.425 \\
\hline Protein yield (g/d) & 389 & 369 & 365 & 265 & 114.8 & 0.040 & 0.055 & 0.140 \\
\hline SCS & 5.24 & 5.13 & 5.30 & 5.31 & 0.364 & 0.194 & 0.650 & 0.519 \\
\hline Lactose (\%) & $4.49^{\mathrm{b}}$ & $4.75^{\mathrm{a}}$ & $4.66^{\mathrm{ab}}$ & $4.54^{\mathrm{ab}}$ & 3.476 & 0.863 & 0.457 & 0.014 \\
\hline
\end{tabular}

a,b Means in the same row with no common superscript differ $(P<0.05)$.

${ }^{1} \mathrm{HO}=$ Holstein cows.

${ }^{2} \mathrm{NO}=$ Normande cows.

${ }^{3} \mathrm{RMSE}=$ root mean squared error.

${ }^{4} \mathrm{HFS}=$ high feeding system.

${ }^{5} \mathrm{LFS}=$ low feeding system 
Table 4. Effect of breed and feeding strategy on animal characteristics

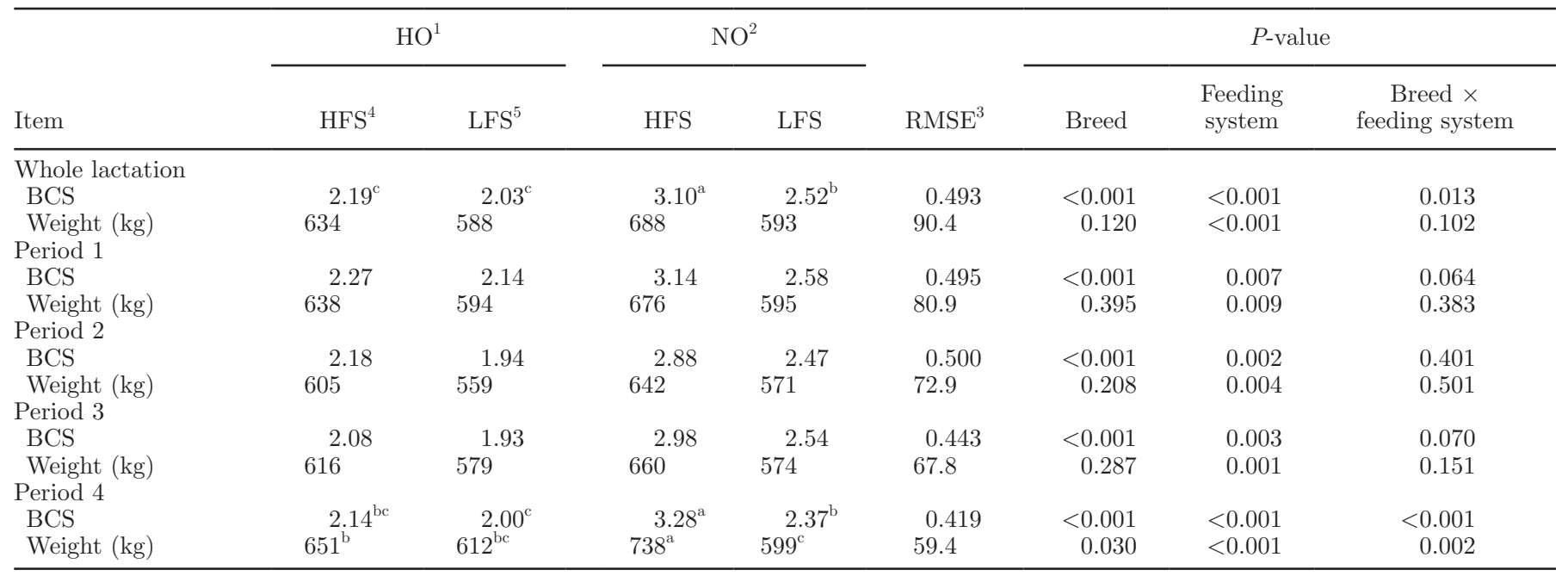

${ }^{\mathrm{a}-\mathrm{c}}$ Means in the same row with no common superscript differ $(P<0.05)$.

${ }^{1} \mathrm{HO}=$ Holstein cows.

${ }^{2} \mathrm{NO}=$ Normande cows.

${ }^{3} \mathrm{RMSE}=$ root mean squared error.

${ }^{4} \mathrm{HFS}=$ high feeding system.

${ }^{5} \mathrm{LFS}=$ low feeding system.

age tended to be higher in HFS compared with LFS in morning milks and was higher in evening milks [1.7 $(P=0.099)$ and 3.6 percentage unit, respectively, for morning and evening milks]. The MUFA percentage was lower in HFS in morning and evening milks $(-2.5$ and -3.8 percentage unit, respectively) during period

Table 5. Effect of breed and feeding strategy on milk fat characteristics during period 1

\begin{tabular}{|c|c|c|c|c|c|c|c|c|c|}
\hline \multirow[b]{2}{*}{ Item } & & \multicolumn{2}{|c|}{$\mathrm{HO}^{1}$} & \multicolumn{2}{|c|}{$\mathrm{NO}^{2}$} & \multirow[b]{2}{*}{$\mathrm{RMSE}^{3}$} & \multicolumn{3}{|c|}{$P$-value } \\
\hline & & $\mathrm{HFS}^{4}$ & $\mathrm{LFS}^{5}$ & HFS & LFS & & Breed & $\begin{array}{l}\text { Feeding } \\
\text { system }\end{array}$ & $\begin{array}{c}\text { Breed } \times \\
\text { feeding system }\end{array}$ \\
\hline \multicolumn{10}{|c|}{ Milk fat characteristics } \\
\hline \multirow[t]{2}{*}{$\mathrm{SL}^{6}$} & $\mathrm{MM}^{7}$ & 0.31 & 0.48 & 0.24 & 0.28 & 0.112 & 0.034 & 0.122 & 0.109 \\
\hline & $\mathrm{EM}^{8}$ & 0.36 & 0.82 & 0.22 & 0.40 & 0.154 & 0.004 & 0.001 & 0.555 \\
\hline \multirow[t]{2}{*}{$\mathrm{iFFA}^{9}$} & MM & 0.14 & 0.13 & 0.13 & 0.11 & 0.027 & 0.051 & 0.101 & 0.580 \\
\hline & EM & 0.12 & 0.15 & 0.12 & 0.11 & 0.036 & 0.072 & 0.579 & 0.071 \\
\hline \multirow{2}{*}{$\mathrm{d}_{4,3}^{10}(\mu \mathrm{m})$} & $\mathrm{MM}$ & 3.80 & 4.28 & 4.20 & 4.32 & 0.557 & 0.112 & 0.028 & 0.152 \\
\hline & EM & 3.87 & 4.28 & 4.29 & 4.40 & 0.681 & 0.094 & 0.113 & 0.356 \\
\hline \multicolumn{10}{|c|}{ Milk fatty acid proportion (\%) } \\
\hline \multirow[t]{2}{*}{ SFA } & MM & 69.2 & 66.0 & 73.7 & 73.5 & 0.42 & $<0.001$ & 0.099 & 0.115 \\
\hline & EM & 66.6 & 61.8 & 72.7 & 70.3 & 0.42 & $<0.001$ & 0.011 & 0.218 \\
\hline \multirow[t]{2}{*}{ MUFA } & MM & 27.1 & 31.2 & 23.0 & 23.8 & 0.42 & $<0.001$ & 0.017 & 0.076 \\
\hline & EM & 29.8 & 34.7 & 23.9 & 26.5 & 0.40 & $<0.001$ & 0.004 & 0.197 \\
\hline \multirow[t]{2}{*}{ cis-9 C18:1 } & MM & $17.3^{\mathrm{b}}$ & $22.5^{\mathrm{a}}$ & $14.8^{\mathrm{c}}$ & $15.9^{\mathrm{c}}$ & 0.41 & $<0.001$ & 0.002 & 0.022 \\
\hline & EM & 20.5 & 26.1 & 15.7 & 18.6 & 0.39 & $<0.001$ & $<0.001$ & 0.138 \\
\hline
\end{tabular}

${ }^{\mathrm{a}-\mathrm{c}}$ Means in the same row with no common superscript differ $(P<0.05)$.

${ }^{1} \mathrm{HO}=$ Holstein cows.

${ }^{2} \mathrm{NO}=$ Normande cows.

${ }^{3} \mathrm{RMSE}=$ root mean squared error.

${ }^{4} \mathrm{HFS}=$ high feeding system.

${ }^{5}$ LFS $=$ low feeding system.

${ }^{6} \mathrm{SL}=$ spontaneous lipolysis, $\mathrm{mEq} / 100 \mathrm{~g}$ of fat.

${ }^{7} \mathrm{MM}=$ morning milkings.

${ }^{8} \mathrm{EM}=$ evening milkings.

${ }^{9} \mathrm{iFFA}=$ initial free fatty acids, $\mathrm{mEq} / 100 \mathrm{~g}$ of fat.

${ }^{10} \mathrm{~d}_{4,3}=\Sigma\left(\mathrm{N}_{\mathrm{i}} \times \mathrm{d}_{\mathrm{i}}^{4}\right) / \Sigma\left(\mathrm{N}_{\mathrm{i}} \times \mathrm{d}_{\mathrm{i}}^{3}\right)$, volume-weighted diameter, where $\mathrm{N}_{\mathrm{i}}$ is the number of fat globules in a size class of diameter $\mathrm{d}_{\mathrm{i}}$. 
Table 6. Effect of breed and feeding strategy on milk fat characteristics during period 2

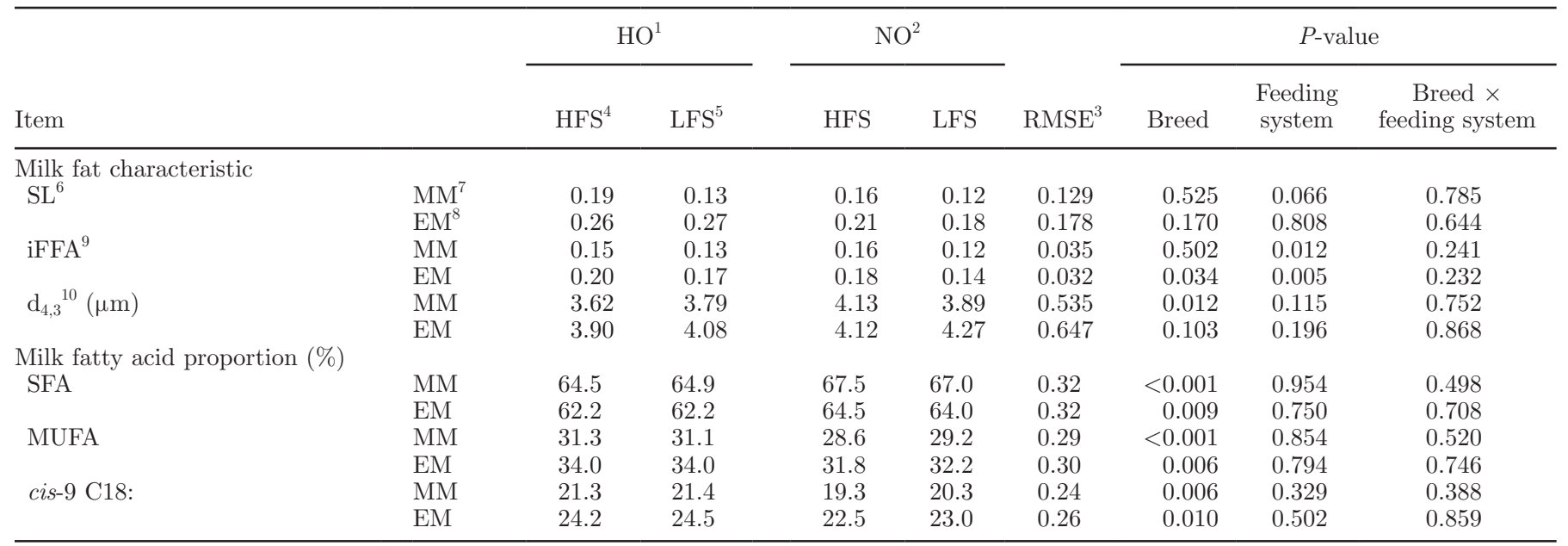

${ }^{1} \mathrm{HO}=$ Holstein cows.

${ }^{2} \mathrm{NO}=$ Normande cows.

${ }^{3} \mathrm{RMSE}=$ root mean square error.

${ }^{4} \mathrm{HFS}=$ high feeding system.

${ }^{5} \mathrm{LFS}=$ low feeding system.

${ }^{6} \mathrm{SL}=$ spontaneous lipolysis, $\mathrm{mEq} / 100 \mathrm{~g}$ of fat.

${ }^{7} \mathrm{MM}=$ morning milkings.

${ }^{8} \mathrm{EM}=$ evening milkings.

${ }^{9} \mathrm{iFFA}=$ initial free fatty acids, $\mathrm{mEq} / 100 \mathrm{~g}$ of fat.

${ }^{10} \mathrm{~d}_{4,3}=\Sigma\left(\mathrm{N}_{\mathrm{i}} \times \mathrm{d}_{\mathrm{i}}^{4}\right) / \Sigma\left(\mathrm{N}_{\mathrm{i}} \times \mathrm{d}_{\mathrm{i}}^{3}\right)$, volume-weighted diameter, where $\mathrm{N}_{\mathrm{i}}$ is the number of fat globules in a size class of diameter $\mathrm{d}_{\mathrm{i}}$.

Table 7. Effect of breed and feeding strategy on milk fat characteristics during period 3

\begin{tabular}{|c|c|c|c|c|c|c|c|c|c|}
\hline \multirow[b]{2}{*}{ Item } & & \multicolumn{2}{|c|}{$\mathrm{HO}^{1}$} & \multicolumn{2}{|c|}{$\mathrm{NO}^{2}$} & \multirow[b]{2}{*}{$\mathrm{RMSE}^{3}$} & \multicolumn{3}{|c|}{$P$-value } \\
\hline & & $\mathrm{HFS}^{4}$ & $\mathrm{LFS}^{5}$ & HFS & LFS & & Breed & $\begin{array}{l}\text { Feeding } \\
\text { system }\end{array}$ & $\begin{array}{c}\text { Breed } \times \\
\text { feeding system }\end{array}$ \\
\hline \multicolumn{10}{|c|}{ Milk fat characteristics } \\
\hline \multirow[t]{2}{*}{$\mathrm{SL}^{6}$} & $\mathrm{MM}^{7}$ & 0.24 & 0.22 & 0.11 & 0.13 & 0.106 & $<0.001$ & 0.789 & 0.408 \\
\hline & $\mathrm{EM}^{8}$ & 0.57 & 0.54 & 0.23 & 0.31 & 0.121 & $<0.001$ & 0.498 & 0.296 \\
\hline \multirow[t]{2}{*}{$\mathrm{iFFA}^{9}$} & $\mathrm{MM}$ & 0.16 & 0.19 & 0.12 & 0.13 & 0.036 & $<0.001$ & 0.063 & 0.474 \\
\hline & EM & 0.19 & 0.16 & 0.15 & 0.12 & 0.030 & $<0.001$ & 0.008 & 0.804 \\
\hline \multirow[t]{2}{*}{$\mathrm{d}_{4,3}{ }^{10}(\mu \mathrm{m})$} & MM & 3.22 & 3.50 & 3.67 & 3.86 & 0.655 & 0.001 & 0.050 & 0.673 \\
\hline & EM & 3.33 & 3.38 & 3.66 & 3.83 & 0.375 & $<0.001$ & 0.222 & 0.500 \\
\hline \multicolumn{10}{|c|}{ Milk fatty acid proportion (\%) } \\
\hline \multirow[t]{2}{*}{ SFA } & MM & 66.0 & 66.5 & 68.3 & 67.6 & 0.39 & 0.068 & 0.545 & 0.943 \\
\hline & EM & 65.6 & 65.9 & 67.3 & 67.9 & 0.38 & 0.040 & 0.601 & 0.887 \\
\hline \multirow[t]{2}{*}{ MUFA } & MM & 30.2 & 29.6 & 28.9 & 28.0 & 0.12 & 0.100 & 0.359 & 0.857 \\
\hline & EM & 30.7 & 30.1 & 29.4 & 28.6 & 0.11 & 0.076 & 0.402 & 0.883 \\
\hline \multirow[t]{2}{*}{ cis-9 C18:1 } & MM & 20.6 & 19.3 & 19.5 & 18.7 & 0.29 & 0.229 & 0.130 & 0.737 \\
\hline & EM & 20.8 & 19.6 & 19.9 & 19.5 & 0.29 & 0.462 & 0.222 & 0.549 \\
\hline
\end{tabular}

${ }^{1} \mathrm{HO}=$ Holstein cows.

${ }^{2} \mathrm{NO}=$ Normande cows.

${ }^{3} \mathrm{RMSE}=$ root mean square error.

${ }^{4} \mathrm{HFS}=$ high feeding system.

${ }^{5} \mathrm{LFS}=$ low feeding system.

${ }^{6} \mathrm{SL}=$ spontaneous lipolysis, $\mathrm{mEq} / 100 \mathrm{~g}$ of fat.

${ }^{7} \mathrm{MM}=$ morning milkings.

${ }^{8} \mathrm{EM}=$ evening milkings.

${ }^{9} \mathrm{iFFA}=$ initial free fatty acids, $\mathrm{mEq} / 100 \mathrm{~g}$ of fat.

${ }^{10} \mathrm{~d}_{4,3}=\Sigma\left(\mathrm{N}_{\mathrm{i}} \times \mathrm{d}_{\mathrm{i}}^{4}\right) / \Sigma\left(\mathrm{N}_{\mathrm{i}} \times \mathrm{d}_{\mathrm{i}}^{3}\right)$, volume-weighted diameter, where $\mathrm{N}_{\mathrm{i}}$ is the number of fat globules in a size class of diameter $\mathrm{d}_{\mathrm{i}}$. 
Table 8. Effect of breed and feeding strategy on milk fat characteristics during period 4

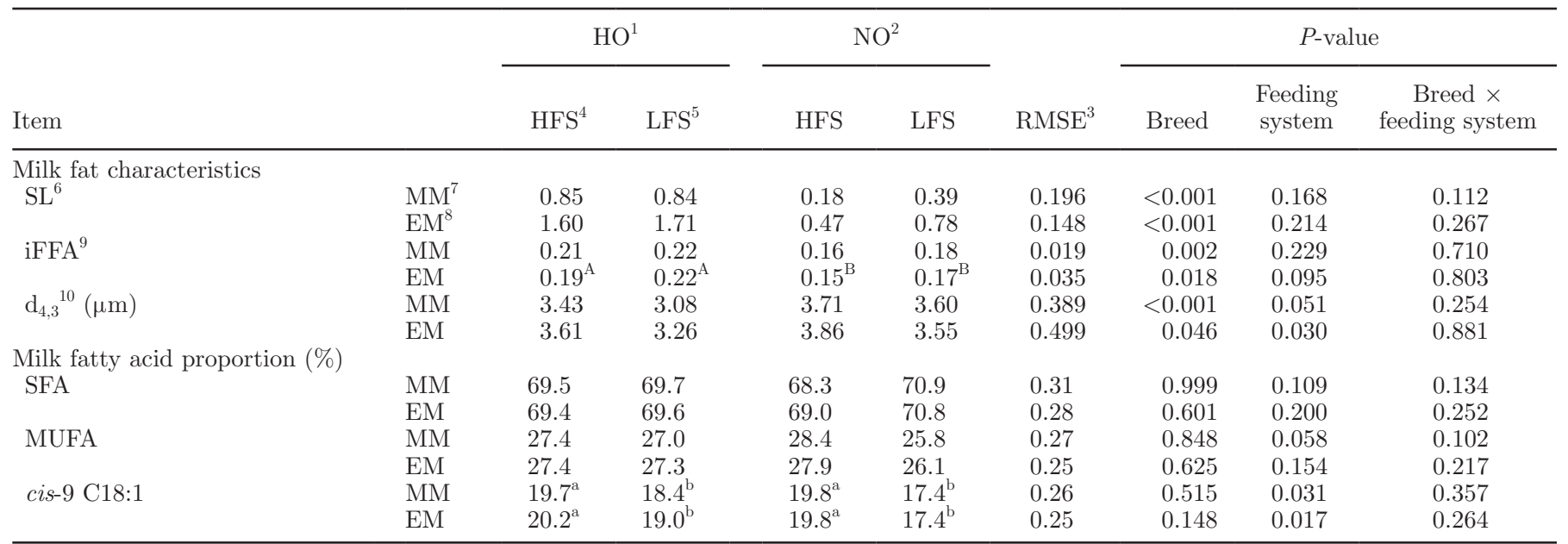

${ }^{1} \mathrm{HO}=$ Holstein cows.

${ }^{2} \mathrm{NO}=$ Normande cows.

${ }^{3} \mathrm{RMSE}=$ root mean squared error.

${ }^{4} \mathrm{HFS}=$ high feeding system.

${ }^{5}$ LFS $=$ low feeding system.

${ }^{6} \mathrm{SL}=$ spontaneous lipolysis, $\mathrm{mEq} / 100 \mathrm{~g}$ of fat.

${ }^{7} \mathrm{MM}=$ morning milkings.

${ }^{8} \mathrm{EM}=$ evening milkings.

${ }^{9} \mathrm{iFFA}=$ initial free fatty acids, $\mathrm{mEq} / 100 \mathrm{~g}$ of fat.

${ }^{10} \mathrm{~d}_{4,3}=\Sigma\left(\mathrm{N}_{\mathrm{i}} \times \mathrm{d}_{\mathrm{i}}^{4}\right) / \Sigma\left(\mathrm{N}_{\mathrm{i}} \times \mathrm{d}_{\mathrm{i}}^{3}\right)$, volume-weighted diameter, where $\mathrm{N}_{\mathrm{i}}$ is the number of fat globules in a size class of diameter $\mathrm{d}_{\mathrm{i}}$.

1 and tended to be higher for HFS in morning milks in period 4 (1.5 percentage units; $P=0.058)$. During period 1, cis-9 C18:1 percentage was lower for HFS in morning and evening milks $(-1.8$ and -1.8 percentage units, respectively; Table 5). During period 4, cis-9 C18:1 percentage was higher in HFS in morning and evening milks (1.9 and 1.8 percentage units, respectively; Table 8$)$.

\section{Factors Affecting Milk SL}

Milking Time. Spontaneous lipolysis was significantly higher in evening milkings compared with morning milkings during the whole experimentation period (0.81 vs. $0.57 \mathrm{mEq} / 100 \mathrm{~g}$ of fat; $P<0.001$ ).

Parity. During the entire lactation, no effect of parity was detected on SL in morning milks $(P=0.180)$, but, in evening milks, SL was higher in multiparous cows during period $1(0.18 \mathrm{mEq} / 100 \mathrm{~g}$ of fat; $P=0.038)$ and lower during periods 3 and $4[-0.17 \mathrm{mEq} / 100 \mathrm{~g}$ of fat $(P=0.024)$ and $-0.66 \mathrm{mEq} / 100 \mathrm{~g}$ of fat $(P=0.018)$, respectively]. No significant interaction between breed and FS effects had been identified on SL.

Breed. Spontaneous lipolysis was higher for $\mathrm{HO}$ cows compared with NO cows in periods 1,3 , and $4(0.13$, 0.11 , and $0.57 \mathrm{mEq} / 100 \mathrm{~g}$ of fat in morning milks and
$0.28,0.28$, and $0.40 \mathrm{mEq} / 100 \mathrm{~g}$ of fat in evening milks, respectively, for periods 1,3 , and 4; Tables 5, 7, and 8).

$\boldsymbol{F S}$. Feeding system did not affect SL throughout lactation for morning or evening milks except for a lower value in HFS $(-0.32 \mathrm{mEq} / 100 \mathrm{~g}$ of fat $)$ in evening milking during period 1 .

Period. To facilitate further interpretation, we recall that the 4 periods in our trial are defined as follows: period 1 corresponds to winter, early lactation, winter diets; period 2 correspond to spring, mid lactation, pasture; period 3 correspond to summer, mid lactation, pasture and period 4 correspond to autumn, late lactation. In morning milks, we found a period $\times$ breed interaction but no period $\times$ FS interaction (Figure 2). For HO cows, SL decreased from period 1 to period 2 $(-0.24 \mathrm{mEq} / 100 \mathrm{~g}$ of fat), was low and stable during periods 2 and 3 , and increased from period 3 to period $4(0.40 \mathrm{mEq} / 100 \mathrm{~g}$ of fat $)$. For NO cows, SL decreased from period 1 to period $2(-0.19 \mathrm{mEq} / 100 \mathrm{~g}$ of fat $)$ and was low and stable during periods 2, 3, and 4 (Figure 2 ). In evening milks, we observed a period $\times$ breed and a period $\times$ FS interaction. In HO-HFS, SL increased during periods 3 and $4(0.25$ and $1.11 \mathrm{mEq} / 100 \mathrm{~g}$ of fat compared with period 1 , respectively). In HO-LFS, SL decreased from period 1 to period $2(-0.55 \mathrm{mEq} / 100$ $\mathrm{g}$ of fat) and increased during periods 3 and 4 ( 0.35 
A

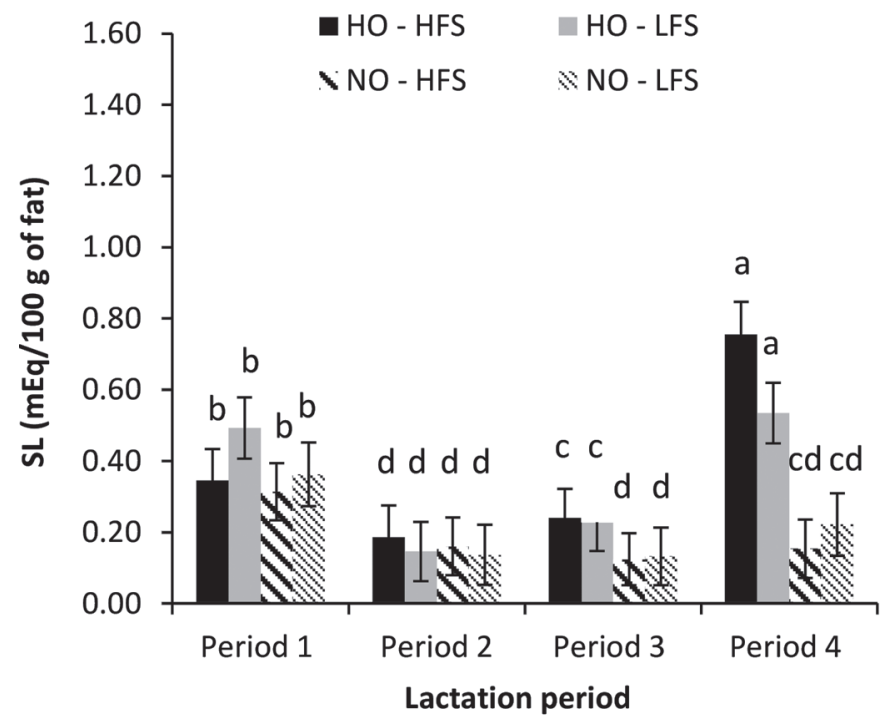

B

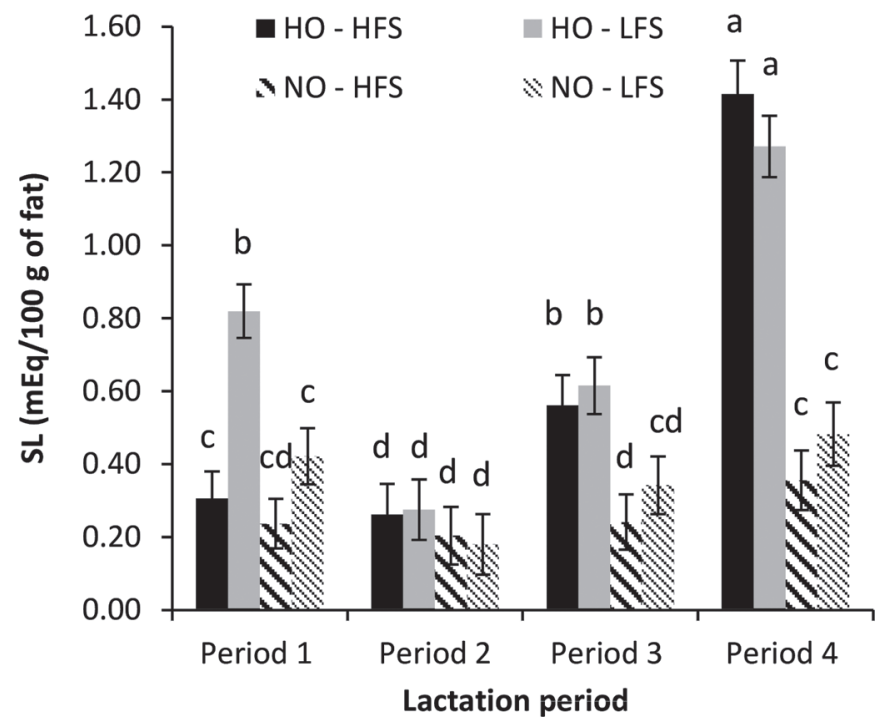

Figure 2. Effect of lactation period on milk spontaneous lipolysis (SL) in morning milks (A) and evening milks (B). The effects of breed, feeding systems, and period are indicated by letters $(\mathrm{a}-\mathrm{d})$, where means in the same row with no common letters differ $(P<0.05)$. HO $=$ Holstein, $\mathrm{NO}=$ Normande, HFS $=$ high feeding system, LFS = low feeding system.

and $1.00 \mathrm{mEq} / 100 \mathrm{~g}$ of fat compared with period 2, respectively). In NO-HFS, SL was low and stable during periods 1,2 , and 3 and slightly increased during period $4(0.12 \mathrm{mEq} / 100 \mathrm{~g}$ of fat compared with period $3)$. In NO-LFS, SL decreased from period 1 to period 2 $(-0.24 \mathrm{mEq} / 100 \mathrm{~g}$ of fat $)$ and increased during periods 3 and $4(0.16 \mathrm{mEq} / 100 \mathrm{~g}$ of fat and $0.30 \mathrm{mEq} / 100 \mathrm{~g}$ of fat compared with period 2 , respectively). In period 4, SL largely increased in $\mathrm{HO}$ cows compared with NO cows; however, this increase was less marked in morning milks compared with evening milks.

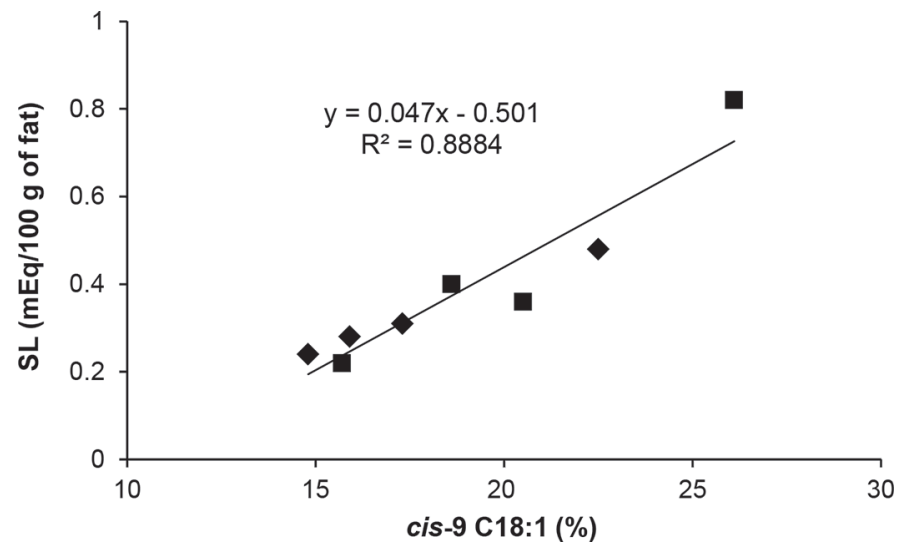

Figure 3. Correlation between cis-9 C18:1 and spontaneous lipolysis (SL) during morning and evening milks in period 1 . Mean values of cis-9 C18:1 and SL were estimated by groups (Normande-high-energy diet, Normande-low-energy diet, Holstein-high-energy diet, Holsteinlow-energy diet) by the mixed procedure of SAS (SAS Institute Inc., Cary, NC). $\bullet=$ morning milks; $\mathbf{\square}=$ evening milks.

\section{Correlations Between SL, Milk Composition, and Animal Characteristics}

During period 1, a high correlation between estimated means by groups (NO-HFS, NO-LFS, HO-HFS, HOLFS) of SL and cis-9 C18:1 was found in morning and evening milks $(\mathrm{r}=0.89, P<0.001$; Figure 3$)$. Poor correlations intertreatment and intercow among lactation, and among periods $(\mathrm{r}<0.16)$ were found between SL and milk yield and milk composition (i.e., fat content, protein content, SCS, lactose content, MFG size, and SFA, C16:0, C18:0, MUFA, cis-9 C18:1, PUFA, $\beta$-CN, $\alpha_{\mathrm{S} 1}-\mathrm{CN}, \alpha_{\mathrm{S} 2}-\mathrm{CN}, \kappa-\mathrm{CN}, \beta-\mathrm{LG}$, and $\alpha$-LA percentages) and animal characteristics (weight, BCS).

\section{DISCUSSION}

\section{Effect of Breed, FS, and Lactation Stage on Milk Traits and Animal Characteristics}

The comparison of NO and HO in terms of milk yield, milk solid content, BCS, and weight is consistent with the literature. As expected, under the same FS, NO cows, compared with HO cows, had lower milk yields, but the milk was richer in protein and fat contents (Dillon et al., 2003; Delaby et al., 2009; Hurtaud et al., 2009), except in early lactation in period 1 . Body condition score was superior in NO cows compared with HO cows (Dillon et al., 2003; Walsh et al., 2008).

Feeding treatments had a strong effect on milk yield, milk fat, and protein yields in early and mid lacta- 
tion. A strong effect of feeding treatments has also been shown on BCS and weight. The LFS reduced milk yield due to feeding restriction, as previously shown in the literature, regardless of the forage-based diet (Delaby et al., 2009; Hurtaud et al., 2009; Burke et al., 2010). The LFS reduced protein yield and the difference in protein yields between both FS was higher than in the literature $[-341 \mathrm{~g} / \mathrm{d}$ in period 1 of our trial compared with -213 and $-204 \mathrm{~g} / \mathrm{d}$ in Hurtaud et al. (2009) and Delaby et al. (2009), respectively]. These differences could be explained by the higher differences in milk yields. Fat content was higher in LFS during period 1 and remained unchanged otherwise; however, fat yield was lower in LFS during the entire lactation. These results are consistent with Gross et al. (2011) for mid lactation, but differ from Hurtaud et al. (2009), Delaby et al. (2009), and Burke et al. (2010), who found a decrease in fat content and fat yield in similar feeding conditions. In our trial, the higher fat content in LFS in early lactation could be explained by the difference in milk yields, as mentioned in the explanation for protein contents. As expected, BCS and weight were higher in HFS compared with LFS during the entire lactation (Delaby et al., 2009; Hurtaud et al., 2009).

\section{Effect of Breed, FS, and Lactation Stage on Milk Fat Characteristics}

Breed. Normande cows secreted larger MFG. These results are consistent with the literature (Couvreur et al., 2006; Hurtaud et al., 2009; Logan et al., 2014), and the differences between breeds were more significant in late lactation.

Normande cows produced milk with higher SFA content and lower MUFA content. Particularly during periods 1 and 2, NO milks contained less cis-9 C18:1 than HO milks. Although Hurtaud et al. (2009) and Couvreur et al. (2006) showed that milk fatty acid profiles differed in both breeds, they did not find any difference in SFA, MUFA, or cis-9 C18:1 contents. In our trial, lower cis-9 C18:1 and MUFA contents could be explained by a lower body fat mobilization rate in NO cows, in accordance with Dillon et al. (2003), van Knegsel et al. (2005), and Delaby et al. (2009).

$\boldsymbol{F S}$. Milk fat globules were larger in LFS during periods 1 and 3. Contrary to Couvreur et al. (2004), we observed an increase in MFG size in the case of feeding restriction. Milk fat globule size is also known to be modulated by the nature of the forage; conserved and fresh grass-based diets are known to lead to MFG size reduction compared with corn silage-based diets (Couvreur and Hurtaud, 2007; Lopez et al., 2010). During period 1, cows from LFS, based on conserved grass, presented larger MFG, suggesting a more important effect of feed restriction compared with nature of forage on MFG secretion mechanisms. These results are not consistent with Hurtaud et al. (2009) in the same conditions. During period 2, both LFS and HFS were fed high-quality pasture, and cows in LFS may have eaten more, compensating for the difference in the diet energy levels and reducing its effect on MFG size. During period 4, MFG were smaller in LFS due to the nature of the forage, and we found lower differences in diet energy levels. Milk fat globule size variations could be explained at a biochemical level by fat and protein content fluctuations during the whole lactation. We found a positive correlation between MFG size and fat content $(r=0.27$; data not shown) and between MFG size and the fat content-to-protein content ratio $(\mathrm{r}=$ 0.37; data not shown), in accordance with Couvreur and Hurtaud (2017). Secretion of fat would correspond to the membrane enwrapping fat droplets in association with the exocytosis of casein micelles vesicles; thus, MFG size would depend on fat and protein contents. Higher fat content would be associated with larger MFG to be adapted to plasmic membrane availability. Lower protein secretion could lead to lower plasmic membrane availability that leads to secretion of larger MFG (Couvreur and Hurtaud, 2017). The LFS was associated with higher MUFA and cis-9 C18:1 contents and lower SFA contents than HFS during period 1; this could be due to higher body fat mobilization linked with reduced nutrient inputs in early lactation (Chilliard et al., 2001; Delaby et al., 2009; Gross et al., 2011). The nature of the provided forage could also explain the difference in fatty acid profiles between HFS and LFS during period 1 (more MUFA and PUFA contents in milk with grass silage vs. corn silage; Hurtaud et al., 2002; Couvreur et al., 2006).

\section{Effect of Milking Time, FS, Breed, and Parity on Milk SL}

Milking Time. Spontaneous lipolysis was higher and fluctuated more in evening milks. Very few studies have evaluated the effect of milking time on SL. Ahrné and Bjork (1985) found higher levels of SL in evening milks, although Bachman et al. (1988) found no difference between morning and evening milks. The difference might be due to the decreased interval (9 vs. $15 \mathrm{~h}$ instead of 12 vs. $12 \mathrm{~h}$ ) between morning and evening milkings (Ahrné and Bjork, 1985; Bachman et al., 1988). Low milk yields ( $<10 \mathrm{~kg}$ for all pregnancy stages and $<5 \mathrm{~kg}$ for pregnancy stages higher than $120 \mathrm{~d}$ ) have been shown to contribute to the increase in milk SL, particularly in evening milks (Chazal and Chilliard, 1986, 1987b), and could explain part of the effects of the milking time, at least in late lactation. 
FS. Spontaneous lipolysis was higher in LFS only during period 1, when cows were fed with conserved grass, in evening milks. In the literature, conserved grass is mainly associated with a lower SL rate than corn silage (Chilliard, 1982; Ferlay et al., 2006); thus, we assumed that the difference in SL during period 1 would be explained by the energy level of the diet, as supported by the positive correlation observed between C18:1, an indicator of lipid mobilization, and SL. Period 1 corresponded to early lactation, when cows might have a negative energy balance and be more sensitive to feed restriction (de Vries and Veerkamp, 2000; Friggens et al., 2007), as also suggested below by fatty acid profile analysis and BCS and weight evaluation. Feeding restriction ( -10 to $-20 \%$ of ingested food) increased SL, especially in late lactation (Stobbs et al., 1973; Chilliard et al., 1986; Jellema 1986; O'Brien et al., 1996) and sometimes in early and mid lactation (Chilliard et al., 1986). The absence of a significant effect of FS on SL during late lactation in our trial might be due to the reduction in the number of dairy cows due to progressive dry off.

The lowest SL levels were observed during pasture periods when cows were in mid lactation (periods 2 and 3 ), in agreement with previous studies (Kuzdzal-Savoie et al., 1975; Chazal et al., 1987), and we found no effect of energy supply, as previously reported by Thomson et al. (2005). Energy balance and nature of forage have been shown to be responsible for changes in milk fat globule membrane (MFGM) composition, which could explain SL variations. As described by Lopez et al. (2008), diets richer in PUFA, such as pasture-based diets or linseed-supplemented diets, are associated with higher levels of phospholipids, particularly sphingomyelin, and higher levels of PUFA in MFGM. Recently, Lu et al. (2013), using a metabolomic approach, found that improved energy balance in cows was associated with higher levels of stomatin, cholesterol, and N-acetylated sugar, which are major components of lipid rafts in MFGM (Lopez et al., 2010). Improved energy balance was thus associated with better membrane integrity, according to those authors. We can assume that changes in MFGM composition could modulate MFG integrity or the proportion of lipoprotein lipase linked to the MFGM, modulating SL levels in milk.

Breed. Milk SL was higher for HO cows compared with NO during the entire lactation (except period 2). An effect of cow breed has already been reported in various experiments comparing $\mathrm{HO}$ and Montbéliarde (Chilliard, 1982; Chazal and Chilliard, 1987a), HO and Jersey (Bachman et al., 1988), and Montbéliarde and Tarentaise (Ferlay et al., 2006). In these trials, HO and Montbéliarde cows had the same level of SL, Jersey cows presented lower levels of SL than HO, and Tarentaise cows presented lower levels of SL than Montbéliarde. In our study, the lower SL levels in NO cows could be attributed to genetics (Vanbergue et al., 2016) or to the difference in lipid metabolism between both breeds. The difference was illustrated by different energy partitions, with higher susceptibility to negative energy balance and adipose tissue mobilization for $\mathrm{HO}$ cows, as also suggested by the fatty acid profile, with higher levels of cis-9 C18:1 for HO cows (Delaby et al., 2009; Hurtaud et al., 2009). As previously discussed, the positive correlation between cis-9 C18:1 and SL would support this argument.

Parity. Multiparous cows were more sensitive to SL in early lactation and less sensitive in mid and late lactation. This is consistent with Chilliard and Lamberet (1984), who found lower SL in multiparous cows' milks. The higher sensitivity of multiparous cows in early lactation could be explained by higher milk production, leading to more negative energy balances and higher adipose tissue mobilization (McNamara et al., 1987; Berry et al., 2008; Delaby et al., 2009), as also supported by cis-9 C18:1 variations according to parity in our trial (data not shown).

Period Effects. The period effect partly reflects the effect of the stage of lactation or pregnancy stage in our study. The large increase in SL in period 4 , when cows are in late lactation and late pregnancy, is consistent with the literature (Arhné and Bjork, 1985; Chazal and Chilliard, 1986, 1987b). The higher levels of SL in period 1 , when cows were in early lactation, compared with period 2 could be explained by the negative energy balance around the lactation peak, in agreement with Kuzdzal-Savoie et al. (1975) and Chazal et al. (1987), as previously discussed. Contrary to Chazal and Chilliard (1986, 1987b), SL decreased between period 1 and 2 . This could be explained by the positive effect of pasture in mid lactation. The higher sensitivity to the lactation stage of evening milks compared with morning milks has already been described by Arhné and Bjork (1985).

Correlation Among Milk SL, Milk Composition, and Animal Characteristics. A high correlation between SL and cis-9 C18:1 was found in period 1 and supported the assumed link between energy balance or tissue mobilization and SL when cows had a negative energy balance. No global correlation and no intertreatment and intercow correlations among lactations and among periods were found between milk yield, fat content, protein content, and SL; this result is consistent with the literature (Cartier and Chilliard, 1990; Stadnik et al., 2015). The MFG size and SL varied concomitantly in some trials (Murphy et al., 1979; Wiking et al., 2006), but we found no direct correlation between MFG size and SL. No correlations were found between SL and major milk fatty acids and major pro- 
teins. To our knowledge, it is the first time that such correlations have been tested.

\section{CONCLUSIONS}

Effects of FS, breed, parity, and lactation stage and the interaction between these factors were clearly identified, thus giving a more comprehensive view of the factors affecting SL at farm scale. These results will help to advise personnel along the milk chain. Spontaneous lipolysis is low at pasture, increases at times of energy deficit, which is always the case in early lactation, but mainly increases at the end of lactation. The SL increase in late lactation could also be due to the gestation stage or low milk yields. Normande cows are less susceptible to SL than HO cows. Spontaneous lipolysis was systematically higher in evening milks compared with morning milks, which could be due to lower milk volume in evening milks or reflect the existence of a putative circadian clock in mammary glands. The mechanisms controlling these effects were not clarified, but apart from the circadian effect, the role of MFGM may be central. Metabolomic approaches would enable the role of minor milk metabolites and of the MFGM in the milk lipolytic system to be described.

\section{ACKNOWLEDGMENTS}

The authors thank all the staff of the experimental farm at le Pin-au-Haras (DEP, INRA, 61310, Exmes, France): S. Blandamour, S. Boulan, B. Camps, Y. Carbonnier, J-L. Deust, J. Gentil, S. Gressin, L. Leloup, D. Pichonat, and L. Vandenbroucke, for the herd management and for their assistance with milk sampling. We are also grateful to P. Debournoux, N. Huchet, C.Perrier, and LILANO (Laboratoire Interprofessionnel Laitier de Normandie, Saint Lô, France) for technical assistance. Thanks are also due to the Join Technical Unit of Research and Engineering on dairy farming (UMT RIEL, Rennes, France) for the constructive exchanges and to Marine Gelé (Institut de l'Elevage, Monvoisin, Le Rheu, France) for fatty acid and protein profiles determination. The authors also thank Gwen Christiansen [INRA-UMR Agroécologie innovation et territoire (AGIR), Castanet Tolosan, France] for her fine work correcting the English in the manuscript. This research received financial support from the CNIEL (Centre National Interprofessionnel de l'Economie Laitière, Paris, France).

\section{REFERENCES}

Ahrné, L., and L. Bjork. 1985. Lipolysis and the distribution of lipase activity in bovine milk in relation to stage of lactation and time of milking. J. Dairy Res. 52:55-64.
Bachman, K. C., M. J. Hayen, D. Morse, and C. J. Wilcox. 1988. Effect of pregnancy, milk vield, and somatic cell count on bovine milk fat hydrolysis. J. Dairy Sci. 71:925-931.

Bazin, S., P. Augeard, M. Carteau, H. Champion, Y. Chilliard, G. Cuylle, C. Disenhaus, G. Durand, R. Espinasse, and A. Gascoin. 1984. Grille de notation de l'état d'engraissement des vaches Pie Noire. ITEB, Paris, France.

Berry, D. P., J. R. Roche, and M. P. Coffey. 2008. Body condition score and fertility-More than just a feeling. Pages 107-118 in Fertility in Dairy Cows: Bridging the Gaps. M. D. Royal, N. C. Friggens, R. F. Smith, ed. British Society of Animal Science, Cambridge University Press, Cambridge, UK.

Burke, C. R. Y. J. Williams, L. Hofmann, J. K. Kay, C. V. C. Phyn, and S. Meier. 2010. Effects of an acute feed restriction at the onset of the seasonal breeding period on reproductive performance and milk production in pasture-grazed dairy cows. J. Dairy Sci. 93:1116-1125.

Cartier, P., and Y. Chilliard. 1990. Spontaneous lipolysis in bovine milk: Combined effects of nine characteristics in native milk. J. Dairy Sci. 73:1178-1186.

Chazal, M. P., and Y. Chilliard. 1986. Effect of stage of lactation, stage of pregnancy, milk yield and herd management on seasonal variation in spontaneous lipolysis in bovine milk. J. Dairy Res. 53:529-538.

Chazal, M. P., and Y. Chilliard. 1987a. Effect of breed of cow (Friesian and Montbéliarde) on spontaneous and induced lipolysis in milk. J. Dairy Res. 54:7-11.

Chazal, M. P., and Y. Chilliard. 1987b. Effets respectifs du stade de lactation, du stade de gestation et du niveau de production sur la lipolyse spontanée du lait de vache. Lait 67:379-392.

Chazal, M.-P., Y. Chilliard, and J. B. Coulon. 1987. Effect of nature of forage on spontaneous lipolysis in milk from cows in late lactation. J. Dairy Res. 54:13-18.

Chilliard, Y. 1982. Variations physiologiques des activités lipasiques et de la lipolyse spontanée dans les laits de vache, de chèvre et de femme: Revue bibliographique. Lait 62:126-154.

Chilliard, Y., M. P. Chazal, and P. Cartier. 1986. Le point sur la lipolyse du lait. Rev. Ecoles Natl. Ind. Lait. 112:12-19.

Chilliard, Y., A. Ferlay, and M. Doreau. 2001. Effect of different types of forages, animal fat or marine oils in cow's diet on milk fat secretion and composition, especially conjugated linoleic acid (CLA) and polyunsaturated fatty acids. Livest. Prod. Sci. 70:31-48.

Chilliard, Y., A. Ferlay, J. Rouel, and G. Lamberet. 2003. A review of nutritional and physiological factors affecting goat milk lipid synthesis and lipolysis. J. Dairy Sci. 86:1751-1770.

Chilliard, Y., and G. Lamberet. 1984. La lipolyse dans le lait: Les différents types, mécanismes, facteurs de variation, signification pratique. Lait 64:544-578.

Chilliard, Y., P. G. Toral, K. J. Shingfield, J. Rouel, C. Leroux, and L. Bernard. 2014. Effects of diet and physiological factors on milk fat synthesis, milk fat composition and lipolysis in the goat: A short review. Small Rumin. Res. 122:31-37.

Couvreur, S., and C. Hurtaud. 2007. Le globule gras du lait: Sécrétion, composition, fonctions et facteurs de variation. INRA Prod. Anim. $20: 369-382$.

Couvreur, S., and C. Hurtaud. 2017. Relationships between milks differentiated on native milk fat globule characteristics and fat, protein and calcium compositions: New insights on milk fat secretion. Animal 11:507-518.

Couvreur, S., C. Hurtaud, L. Delaby, and J. L. Peyraud. 2004. Effect of haylage or maize silage based diets with or without energy restriction on milk fat properties. Pages 1142-1144 in Grassland Sci. Eur. Proc., vol. 9. Luzern, Switzerland. Swiss Grassland Society, Zürich, Switzerland.

Couvreur, S., C. Hurtaud, and J. L. Peyraud. 2006. Variabilité de la taille et de la composition en acides gras des globules gras du lait chez la vache laitière. Rencontres Autor Rech. Rumin. 13:301-304.

Deeth, H. C. 2006. Lipoprotein lipase and lipolysis in milk. Int. Dairy J. 16:555-562. 
Delaby, L., P. Faverdin, G. Michel, C. Disenhaus, and J. L. Peyraud. 2009. Effect of different feeding strategies on lactation performance of Holstein and Normande dairy cows. Animal 3:891-905.

Delaby, L., and J. L. Peyraud. 2003. The effect of two contrasting grazing managements and level of concentrate supplementation on the performance of grazing dairy cows. Anim. Res. 52:437-460.

de Vries, M. J., and R. F. Veerkamp. 2000. Energy balance of dairy cattle in relation to milk production variables and fertility. J. Dairy Sci. 83:62-69.

Dillon, P., F. Buckley, P. O'Connor, D. Hegarty, and M. Rath. 2003. A comparison of different dairy cow breeds on a seasonal grass-based system of milk production. 1. Milk production, live weight, body condition score and DM intake. Livest. Prod. Sci. 83:21-33.

Dillon, P., J. R. Roche, L. Shalloo, and B. Horan. 2005. Optimising financial return from grazing in temperate pastures. Pages 131148 in Utilisation of Grazed Grass in Temperate Animal Systems. Proc. satellite workshop of the XXth Int. Grassl. Congr. J. J. Murphy, ed. Wageningen Academic Publishers, Wageningen, the Netherlands.

Ferlay, A., B. Martin, P. Pradel, J. B. Coulon, and Y. Chilliard. 2006 Influence of grass-based diets on milk fatty acid composition and milk lipolytic system in Tarentaise and Montbeliarde cow breeds. J. Dairy Sci. 89:4026-4041.

Ferrand-Calmels, M., I. Palhiere, M. Brochard, O. Leray, J. M. Astruc, M. R. Aurel, S. Barbey, F. Bouvier, P. Brunschwig, H. Caillatt, M. Douguet, F. Faucon-Lahalle, M. Gelé, G. Thomas, J. M. Trommenschlager, and H. Larroque. 2014. Prediction of fatty acid profiles in cow, ewe, and goat milk by mid-infrared spectrometry. J. Dairy Sci. 97:17-35.

Friggens, N. C., P. Berg, P. Theilgaard, I. R. Korsgaard, K. L. Ingvartsen, P. Lovendahl, and J. Jensen. 2007. Breed and parity effects on energy balance profiles through lactation: Evidence of genetically driven body energy change. J. Dairy Sci. 90:5291-5305.

Gelé, M., S. Minery, J. M. Astruc, P. Brunschwig, M. Ferrand-Calmels, G. Lagriffoul, H. Larroque, J. Legarto, O. Leray, P. Martin, G. Miranda, I. Palhiere, P. Trossat, and M. Brochard. 2014. Phénotypage et génotypage à grande échelle de la composition fine des laits dans les filières bovine, ovine et caprine. INRA Prod. Anim. $27: 255-268$.

Gross, J., H. A. van Dorland, R. M. Bruckmaier, and F. J. Schwarz. 2011. Milk fatty acid profile related to energy balance in dairy cows. J. Dairy Res. 78:479-488.

Hoden, A., J. L. Peyraud, A. Muller, L. Delaby, P. Faverdin, J. R. Pecatte, and M. Fargetton. 1991. Simplified rotational grazing management of dairy cows: Effects of rates of stocking and concentrate. J. Agric. Sci. 16:417-428.

Hurtaud, C., L. Delaby, and J. L. Peyraud. 2002. Evolution of milk composition and butter properties during the transition between winter-feeding and pasture. Grassland Sci. Eur. Proc. 7:574-575.

Hurtaud, C., J. L. Peyraud, G. Michel, D. Berthelot, and L. Delaby 2009. Winter feeding systems and dairy cow breed have an impact on milk composition and flavor of two Protected Designation of Origin French cheeses. Animal 3:1327-1338.

Institut National de la Recherche Agronomique (INRA). 2007. Ruminant nutrition: Recommended allowances and feed tables. R. Jarrige, ed. John Libbey, London, UK.

Jellema, A. 1986. Some factors affecting the susceptibility of raw cow milk to lipolysis. Milchwissenschaft 41:553-558.

Kolver, E. S., J. R. Roche, M. J. de Veth, P. L. Thorne, and A. R. Napper. 2002. Total mixed rations versus pasture diets: Evidence for a genotype diet interaction in dairy cow performance. Proc. N.Z. Soc. Anim. Prod. 62:246-251.

Kuzdzal-Savoie, S., J. E. Auclair, R. Mourgues, and D. Langlois. 1975. La lipolyse dans le lait refroidi. Lait 55:530-543.

Le Gall, A., E. Béguin, J. B. Dollé, V. Manneville, and A. Pflimlin. 2009. Nouveaux compromis techniques pour concilier efficacité économique et environnementale en élevage herbivore. Fourrages (Versailles) 198:131-151.
Logan, A., M. Auldist, J. Greenwood, and L. Day. 2014. Natural variation of bovine milk fat globule size within a herd. J. Dairy Sci. 97:4072-4082.

Lopez, C., V. Briard-Bion, O. Menard, F. Rousseau, P. Pradel, and J. M. Besle. 2008. Phospholipid, sphingolipid, and fatty acid compositions of the milk fat globule membrane are modified by diet. J. Agric. Food Chem. 56:5226-5236.

Lopez, C., M. N. Madec, and R. Jimenez-Flores. 2010. Lipid rafts in the bovine milk fat globule membrane revealed by the lateral segregation of phospholipids and heterogeneous distribution of glycoproteins. Food Chem. 120:22-33.

Lu, J., E. Antunes Fernandes, A. E. Páez Cano, J. Vinitwatanakhun, S. Boeren, T. van Hooijdonk, A. van Knegsel, J. Vervoort, and K. A. Hettinga. 2013. Changes in milk proteome and metabolome associated with dry period length, energy balance, and lactation stage in postparturient dairy cows. J. Proteome Res. 12:3288-3296.

McNamara, J. P., D. C. McFarland, and S. Bai. 1987. Regulation of bovine adipose tissue metabolism during lactation. 3. Adaptations of hormone-sensitive and lipoprotein lipases. J. Dairy Sci. 70:1377-1384.

Murphy, J. J., J. F. Connolly, and D. R. Headon. 1979. A study of factors associated with free fatty acid development in milk. Ir. J. Agric. Food Res. 3:131-149.

O'Brien, B., S. Crosse, and P. Dillon. 1996. Effects of offering a concentrate or silage supplement to grazing dairy cows in late lactation on animal performance and on milk processability. Ir. J. Agric. Food Res. 35:113-125.

Peyraud, J. L., and R. Delagarde. 2013. Managing variations in dairy cow nutrient supply under grazing. Animal 7:57-67.

Pflimlin, A., P. Faverdin, and C. Béranger. 2009. Un demi-siècle d'évolution de l'élevage bovin. Bilan et perspectives. Fourrages (Versailles) 200:429-464.

Raison, C., H. Chambault, A. Le Gall, and A. Pflimlin. 2008. Impact du système fourrager sur la qualité des eaux. Enseignements issus du Projet Green Dairy. Fourrages (Versailles) 193:3-18.

Scanlan, R. A., L. A. Sather, and E. A. Day. 1965. Contribution of free fatty acids to the flavor of rancid milk. J. Dairy Sci. 48:1582-1584.

Shipe, W. F., G. F. Senyk, and K. B. Fountain. 1980. Modified copper soap solvent extraction method for measuring free fatty acids in milk. J. Dairy Sci. 63:193-198.

Stadnik, L., J. Duchacek, R. Tousova, J. Beran, M. Ptacek, and L. Kourimska. 2015. Relations between basic milk components and free fatty acid content in Holstein cow milk as lipolysis parameter. Mljekarstvo 65:18-25.

Stobbs, T. H., H. C. Deeth, and C. H. Fitz-Gerald. 1973. Effect of energy intake on spontaneous lipolysis in milk from cows in late lactation. Aust. J. Dairy Technol. 28:170-172.

Thomson, N. A., W. C. Van der Poel, M. W. Woolford, and M. J. Auldist. 2005. Effect of cow diet on free fatty acid concentrations in milk. N. Z. J. Agric. Res. 48:301-310.

van Knegsel, A. T. M., H. Van den Brand, J. Dijkstra, S. Tamminga, and B. Kemp. 2005. Effect of dietary energy source on energy balance, production, metabolic disorders and reproduction in lactating dairy cattle. Reprod. Nutr. Dev. 45:665-688.

Vanbergue, E., J. L. Peyraud, J. Guinard-Flament, C. Charton, S. Barbey, R. Lefebvre, Y. Gallard, and C. Hurtaud. 2016. Effects of DGAT1 K232A polymorphism and milking frequency on milk composition and spontaneous lipolysis in dairy cows. J. Dairy Sci. 99:5739-5749.

Walsh, S., F. Buckley, K. Pierce, N. Byrne, J. Patton, and P. Dillon. 2008. Effects of breed and feeding system on milk production, body weight, body condition score, reproductive performance, and postpartum ovarian function. J. Dairy Sci. 91:4401-4413.

Wiking, L., J. H. Nielsen, A. K. Båvius, A. Edvardsson, and K. Svennersten-Sjaunja. 2006. Impact of milking frequencies on the level of free fatty acids in milk, fat globule size, and fatty acid composition. J. Dairy Sci. 89:1004-1009. 